\title{
Антропология
}

\section{девиантного поведения}

\section{УAK 572.02:342.2}

DOI: 10.35750/2713-0622-2021-1-39-50
OPEN ACCESS

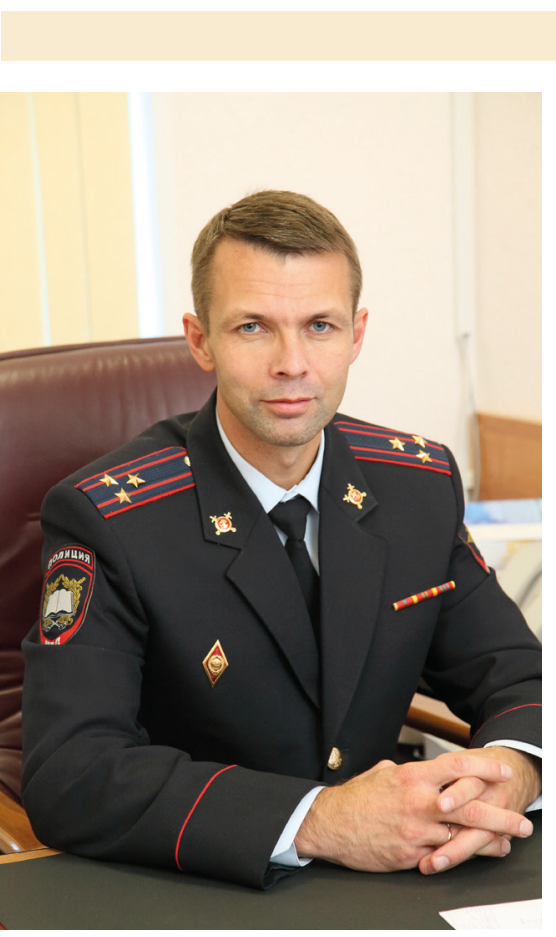

\section{Бавсун \\ Максим Викторович}

Санкт-Петербургский

университет МВА России

(Санкт-Петербург, Россия)

kafedramvd@mail.ru

ORCID: 0000-0002-1407-2609
Научная статья

\section{Антропологические предпосылки формирования современной уголовной биополитики}

\section{Аннотация}

Биополитика начинает занимать все больше места в современном представлении государства о его возможностях в выборе средств, необходимых для оказания на каждого индивида в отдельности и общество в целом требуемого влияния. Пределы таких возможностей с учетом накопленных человечеством знаний в последние несколько десятилетий оказались по-настоящему неограниченными, с неизбежностью формулируя вопрос относительно постановки конкретных целей и задач, подразумеваемых властью. Функция контроля всегда была присуща официально властному образованию, а проблема определения пределов ее реализации также всегда находилась в сфере разногласий, формируя различные типы обществ и государств. Биополитика - явление принципиально нового порядка, способное вывести обсуждение данной проблемы на недоступный ранее уровень. Пока же уголовно-правовая составляющая представленного вопроса настойчиво игнорируется научным сообществом, хотя невозможно не обращать внимания на происходящие процессы, а особенно на трансформацию общественных отношений, аналогов которой по своему масштабу в истории не так много. Однако именно уголовная политика, посредством введения в оборот биополитического инструментария, способна оказать наибольшее влияние на формирование и реализацию функции контроля индивидуального поведения человека и общественных отношений в целом. Функция, которая сегодня не является характерной для уголовно-правовой сферы, в конечном итоге способна выступить в качестве одной из основных в ходе реализации данного направления правового регулирования.

\section{Киючевые слова}

антропология, биополитика, общественные отношения, уголовная политика, девиантное поведение

Для цитирования: Бавсун, М. В. (2021) Антропологические предпосылки формирования современной уголовной биополитики. Российский девиантологический журнал, 1(1), 39-50. doi: 10.35750/2713-0622-2021-1-39-50. 


\section{Anthropology of Deviant Behavior}

Scientific article

\section{Maksim V. Bavsun}

Saint Petersburg University of the MIA of Russia (Saint Petersburg, Russia)

kafedramvd@mail.ru

ORCID: 0000-0002-1407-2609

\section{Anthropological Prerequisites for Contemporary Criminal Biopolicy Formation}

\section{Abstract}

Biopolicy gets to play more important role in the way the state regards the opportunity of choosing necessary means that can be used to influence both a person and a society.

In terms of knowledge accumulated by humanity over the past few decades the boundaries of these possibilities appear to be really unlimited. All these factors lead to the question about definite goals and tasks implied by the authority.

The control function has always been inherent in an official authority and the problem of defining control limits implementation has also been within the sphere of disagreement creating different types of societies and states.

Biopolicy appears to be a new fundamental notion and seems to be able to bring out the discussion of the problem to previously unavailable level. The fact is that the legal component of the issue has insistently remained far apart not taking into account ongoing processes particularly public relations transformation which has had few analogues in its scope in the course of history. It is the criminal policy that can have the strongest impact on the formation and implementation of the control function of both an individual's behavior and public relations through the introduction of biopolitical tools.

The function that is not typical of the criminal law sphere today is ultimately able to act as one of the main functions in legal regulation implementation.

\section{Keywords}

anthropology, biopolicy, public relations, criminal policy, deviant behavior

For citation: Bavsun, M. V. (2021). Anthropological basis of formation modern criminal biopolitics. Russian Journal of Deviant Behavior, 1(1), 39-50. doi: 10.35750/2713-0622-2021-1-39-50.

Антропологическое направление в отечественной теории и практике уголовного права не является распространенным, что во многом объяснимо длительным доминированием в доктрине классической и социологической школ. На всем протяжении развития российской уголовно-правовой мысли идеи о серьезном влиянии биологической природы человека на его поведение (в том числе и девиантное) не находили соответствующего понимания у российских специалистов. Отдельные высказывания в поддержку, но - увы! - далеко не исследования можно встретить в некоторых работах конца XVIII и всего XIX столетий, посвященных уголовно-правовой проблематике и ее философскому обоснованию. Так, Г. С. Фельдштейн, поднимая работы П. Калмыкова, отмечает его некоторую приверженность антропологии (т. е. учету знаний анатомии, физиологии, медицины и психологии) в праве в самом обширном смысле. К этим главным источникам, по мнению ученого, «присоединяются еще другие источники второстепенные, как то: положительные уголовные законы и юридические уголовные обычаи всех народов и всех времен» (Фельдштейн, 2003, с. 391). В то же время, если посмотреть работы авторов этого же периода, то последователей данной позиции в отечественной доктрине можно встретить немного. Ф. В. Ушаков, А. Н. Радищев, И. В. Лопухин или М. Щербатов (вторая половина XVIII века) не являлись сторонниками идей антропологического свойства. Например, И. В. Лопухин вообще не верил в осуществимость полного приспособления наказания к особенностям конкретного случая, что уже само собой исключало его индивидуализацию на основе биометрических показателей преступника (Фельдштейн, 2003, с. 393). М. Щербатов в этом отношении пошел еще дальше, последовательно 
отстаивая идеи крайне жестких наказаний в России применения смертной казни, а также телесных наказаний преимущественно к людям низших сословий, что также далеко от учета биологических особенностей преступника. Г. И. Солнцев, О. И. Горегляд, П. Н. Гуляев и другие ученые этого исторического периода строили свои работы в основном вокруг разработки новых уголовно-правовых институтов, основ системы Особенной части, отдельных категорий уголовного права, а также анализа тех или иных видов или групп преступлений, вообще не поднимая вопросов антропологии или социологии уголовного права (Солнцев, 1820), (Горегляд, 1815), (Гуляев, 1826).

$\mathrm{He}$ встречает поддержки антропологическое направление и в работах отечественных юристов более позднего периода. Так, С. И. Баршев, рассуждая на данную тему, полагает, что человек должен быть наказываем не более того, что он заслужил своими делами (Баршев, 1840), обращая при этом внимание на доминирование объективной стороны над всеми другими факторами, способствующими выбору конкретного вида и размера наказания. В целом отмеченный подход был характерен для отечественных юристов этого времени, что вполне объяснимо с позиции предыдущего этапа развития русского уголовного права, олицетворявшего формирование в большей мере догматического представления о законе и его применении. Подтверждением тому являются последующие работы Н. С. Таганцева, С. И. Будзинского, Н. Д. Сергиевского, В. Д. Спасовича и некоторых других авторов, последовательно отстаивавших классическое направление в уголовном праве. Так, Н. С. Таганцев писал, что «соединение в одну единую науку социологического, антропологического и юридического исследования преступления и преступника теоретически не соответствовало бы основным началам классификации отдельных отраслей знания, а практически послужило бы только ко взаимному вреду разработки этих отдельных отраслей исследования, так как они разнятся и по методам или приемам изучения материала, и по преследуемым ими целям» (Таганцев, 1903, с. 31). При этом Г. Тард

в это же время писал буквально следующее: «Сколько антропологов, столько и различных преступных типов. Марро не соглашается с Ломброзо, а Ломброзо - сам с собой» (Тард, 2009, с. 15).

Не был сторонником исследуемого направления и С. К. Гогель, который крайне иронично отзывался о сути захватившей умы ведущих ученых этого периода идеи биометрических показателей, позволяющих оценить так называемых типовых преступников. В то же время, критикуя саму постановку вопроса, в целом автор полагает, что, несмотря на слишком поспешные выводы школы Ч. Ломброзо, после ее появления будет грубейшей ошибкой полное отри-

99 цание значения индивидуальных факторов личности в ходе установления причин совершения конкретного преступления (Гогель, 1910 , с. 104). Солидарен с ним был и М. П. Чубинский, ставивший в заслугу ученым-антропологам разработку огромного объема нового фактического материала, который позволил описать преступника в действительности, в то время как до антропологических исследований были лишь абстрактные рассуждения о преступнике в тиши ученых кабинетов (Чубинский, 1905).

Что характерно, критикуя новое направление, юристам вторили и отечественные философы мирового уровня. Например, В. С. Соловьев достаточно категорично утверждал, что не считает криминальную «антропологию» «...новооткрытой Америкой», и полагал, что «...это есть тот ошибочный “путь в Индию”, который приведет, может быть, к открытию нового мира» (Соловьев, 2014, с. 194). П. А. Сорокин, полемизируя с Гарофало и Ферри, отмечает, что совершенно невозможно установление антропологического типа преступника ввиду изменчивости самого понятия преступления, его постоянной исторической трансформации. При этом ученый активно ссылается на работы Ж. Фино «Агония и смерть человеческих рас», А. Принса «Преступность и репрессии», а также И. Я. Фойницкого «Учение о наказании», подвергшие критике антропологическое направление и показавшие ложность сформулированных в его рамках выводов ${ }^{1}$ (Сорокин, 2006).

\footnotetext{
Основное внимание при этом учёный уделяет критике самого подхода деления людей по типологии и отсутствию реальной возможности такой классификации, отсутствию таких критериев, которые могли бы быть распространены на всех (Сорокин, 2006, с. 146-152).
} 
Надо сказать, что общий отрицательный фон исследуемого направления в целом был типичен и для официальной позиции по данному вопросу. Несмотря на то, что в 1885 г. на конгрессе в Риме, посвященном вопросам уголовного права, представители антропологического направления торжествовали, уже в 1889 г. в Париже им пришлось выслушивать самые решительные возражения со стороны медицинских светил Франции - Бруарделя, Манувье и других. Более того, как указывает М. Н. Гернет, возражения в ходе данного действа все больше напоминали откровенный протест, а самому Ч. Ломброзо пришлось вспомнить римскую пословицу «От триумфа до Тарпейской скалы всего один шаг» (Гернет, 1974, с. 230). Видимо, в том числе и по этой причине уже в 1892 г. ни Ч. Ломброзо, ни его сторонники конгресс в Женеве не посетили. При этом на следующем конгрессе в 1896 г. ведущие немецкие психиатры подвергли самой серьезной обструкции идею прирожденного преступника, составлявшую суть всего учения (Гогель, 1910, с. 96).

Хотя следует признать, что как раз западная наука, в отличие от российской, была не столь категорична в решении данного вопроса. Более того, даже официальная позиция в ходе его исследования была не настолько однозначна, как может показаться на первый взгляд, несмотря на всю категоричность приведенных формулировок. Дело в том, что ведущие немецкие, французские и в особенности английские медики, психиатры и юристы негативно реагировали в большей степени на идею именно прирожденного преступника, но не на сам факт необходимости выделения тех или иных биологических особенностей и их биометрических показателей, указывающих на некую предрасположенность к совершению тем или иным лицом преступления. Как раз этот аспект учения не вызывал особых возражений среди большинства специалистов. Было немало дебатов относительно того, какие конкретно должны быть показатели, но это были разногласия творческого характера, и ни у кого не вызывало сомнений, что рано или поздно они будут определены.

В качестве одного из сторонников указанной идеи в таком ее виде в данный период выступал, например, Г. Ашаффенбург, работы которого стали важным событием в истории развития юридической психологии.
Ученый - один из немногих, кто рассмотрел роль индивидуально-наследственных и социально-экологических факторов в формировании преступного поведения. Подвергая критике концепцию Ч. Ломброзо о «врожденном преступнике», он не только разработал собственную доктрину, но и высказал при этом идею о необходимости наличия у судьи знаний о биологических особенностях преступника, а также о его владении азами психологии и психиатрии (Ашаффенбург, 2010 , с. 9). Индивидуальные особенности личности виновного не меньше оценивали Ф. Лист, Д. А. Дриль и некоторые другие специалисты, полагая эти знания ничуть не менее значимыми, чем представления о конкретных законодательных нормах (Лист, 1900, c. 5-7), (Дриль, 1904 , с. 1220), (Чиж, 1895). Отстаивала этот подход и П. Н. Тарновская - врач-невропатолог по образованию, занимающаяся проблемами криминальной антропологии. Именно она на тот момент в силу своей профессиональной принадлежности, полученного образования и проводимых исследований была ближе всех к этим идеям и реализовывала их на уровне самостоятельных исследований (Тарновская, Женщины-убийцы. Антропологическое исследование, 1902), (Тарновская, Воровки. Антропологическое исследование, 1891, с. 63-64).

Между тем надо понимать, что перечисленные ученые, включая и Ч. Ломброзо, были далеко не первыми, кто целенаправленно анализировал проблемы влияния биологических особенностей человека на совершение преступлений. Они опирались на результаты исследований, которые были получены еще задолго до них, начиная со второй половины XVII века. Что характерно, исследования эти были проведены исключительно иностранными специалистами (в основном речь идет об английской и отчасти немецкой школах психиатрии), и все они были реализованы, в первую очередь, в сфере медицины, а точнее, в психиатрии.

Л. М. Прозументов пишет по этому поводу, что предшественники Ч. Ломброзо задолго до него и совершенно независимо от него обосновывали наличие особого типа преступника. Среди таких ученых особо выделяются: Дж. Причард (1786-1848 гг.) «Трактат о помешательстве»; Г. Модсли (1771-1831 гг.) «Физиология и патология души», «Ответственность при ду- 
шевных болезнях»; Б. Томсон «Психология преступников», «Наследственная природа преступления»; Д. Уилсон «Моральное слабоумие привычных преступников по данным измерения черепов»; И. К. Лафатер «Физиогномика»; Ф. Й. Галль (основатель френологии) и др. (Торвальд, 1990) ${ }^{2}$. В этот же период появляются работы Г. Д. Гардена, Д. Никольсона, В. Кларка, В. Д. Моррисона и других исследователей о проблемах уголовной антропологии, в которых поведение преступников обосновывается с позиции их ненормальности, психической неуравновешенности, наследственности и др. Результаты их деятельности в этом направлении были опубликованы раньше широко известного труда Ч. Ломброзо (Прозументов, О происхождении антропологического направления в уголовном праве и криминологии, 2016, с. 20-27). Иданный факт является крайневажнымспозиции осознания того, что антропологическое направление получило на Западе значительно более ранний старт своего развития, что в конечном итоге повлекло за собой бурный всплеск интереса к проблеме во второй половине XIX века. Однако следует признать, что этот интерес возник не сам по себе, а имел достаточно серьезную основу, в отмеченный период лишь окончательно оформившись в самостоятельное направление.

В свою очередь в России на данные вопросы обратили соответствующее внимание лишь во второй половине XIX столетия, подвергнув оценке их содержание с догматической (совершенно бесполезной в данном случае) позиции. К тому моменту классическое направление уже всецело доминировало в отечественном уголовном праве, тоже, кстати, имея свою историческую подоплеку, включая соответствующее обоснование, и строящееся на его основе видение. Тогда же мощный импульс получила и социологическая школа, достаточно быстро заняв свою нишу в доктрине и оказывая существенное влияние и на законодательство. Современному юристу на тот момент антропологические идеи во многом оказались чуждыми по вполне объективным причинам. Такова историческая, культурная, ментальная и др. подоплека данного феномена. Точно такая же она и применительно к западноевропейскому обществу, естественно, с присущими ему особенностями. По большому счету на рубеже XIX-XX столетий произошел окончательный выбор направления движения как в части исследований в уголовно-правовой доктрине, так и в части формирования уголовного законодательства. Очевидно, что выбор этот в России и в западноевропейских странах (безусловно, не везде однородно) был различен ${ }^{3}$. Идейная составляющая такой ситуации сегодня не вызывает каких-либо сомнений. Как следствие, различное видение причин совершения отдельных видов преступлений, различное отношение к природе происхождения человека и значимости его конкретных биометрических показателей и особенностей при совершении преступных посягательств в конечном итоге привели и к разработке существенно отличающихся друг от друга как средств частной превенции, так и в особенности средств ресоциализации.

Но это уже последствия вторичного характера. В первую очередь это повлекло дальнейшую разработку самих идей, которые не могли длительное время оставаться в заданных пределах. Их трансформация происходила сообразно уже полученным знаниям, изменениям политического (что важно - геополитического) и мирового свойства в целом. Немаловажное влияние на этот процесс оказывала экономическая составля-

\footnotetext{
2 Надо сказать, что в реализацию данных исследований непосредственно на практике внесли свой вклад «Рудольф Райе в Лозанне, Роберт Гейндл в Мюнхене, Дрездене и Берлине и Эдмон Локар в Лионе» - именно они «являются первыми борцами за создание полицейских лабораторий, в которых нашли бы своё применение при расследовании преступлений все достижения науки и техники» (Торвальд, 1990, с. 208-209).

3 Отметим, что как вполне логичное продолжение проявившегося в России в отмеченный период интереса к криминальной антропологии, после революции 1917 г. наблюдался некоторый всплеск идей в развитие данной теории. По сути, этот всплеск был последним и носил характер больше инерции, чем целенаправленности (Познышев, 2007, с. 35). Как отмечают современные ученые, «основная причина распространения антропологических теорий состояла в догматическом восприятии последователями общеидеологических «постулатов» марксизма об антикриминогенном характере социализма. Исследователи изначально исходили из того, что после Октябрьской революции были «подорваны социальные корни преступности». Такая посылка означала, что причины преступности должны вытекать из каких-либо особых свойств личности преступника. Однако антропологические выводы психиатров скоро пришли в очевидное противоречие с марксистской доктриной, исходящей из социальной природы преступности. Теоретические заблуждения сторонников биологического изучения преступников в совокупности с господствовавшей государственной идеологией и реальными успехами в борьбе с преступностью привели к негативным последствиям: в 30-х гг. криминологические исследования были практически свернуты, а проводившие их учреждения были либо закрыты, либо перепрофилированы на разработку проблем так называемой исправительно-трудовой политики» (Прозументов, Л. М., Шеслер, А. В., 2014 , с. 53). В конечном итоге можно констатировать факт доминирующего влияния внешних обстоятельств на развитие исследуемого явления, когда столкновение различных по своей сути идей оказалось фатальным для части из них. В советский период к собственно антропологическим идеям обращался разве что И. С. Ной, который, впрочем, также лишь высказывался в поддержку, не занимаясь исследованиями в данном направлении (Ной, 1975).

Попытки выхода за пределы в чистом виде криминологии, безусловно, предпринимались, однако обращения эти в большинстве случаев были и остаются эпизодичными. В итоге криминологические задачи решались силами самих криминологов с использованием главным образом собственного ресурса криминологии, которого сегодня оказалось явно недостаточно (Бабаев, М. М., Пудовочкин, Ю. Е., 2021, с. 292). В итоге, как эмоционально пишет В. С. Овчинский, «либо действительно наступит конец криминологии, либо криминологам придется овладеть новейшими знаниями в области психиатрии, психологии, психогенетики, медицинской генетики и других естественных наук» (Овчинский, 2005, с. 28).
} 
ющая, демографическая обстановка, географические, климатические, психологические (и опять же их постоянное изменение) и иные факторы, зачастую обусловленные деятельностью самого человека. Если брать антропологическое направление, то его прогнозируемый ренессанс сегодня (завтра) обусловлен, во-первых, уже имеющейся прочной основой, полученной в обозначенном выше периоде (и последовательным развитием), а во-вторых, бурным ростом научных достижений в сфере медицины, морфологии, биохимии, психологии, психиатрии, а в последние несколько десятилетий - и генной инженерии, наряду с сопутствующим им технологическим прогрессом. Именно они в своей совокупности открыли бескрайние возможности в выяснении человеческой природы (вплоть до объяснения происхождения и возможного клонирования), и, уже как следствие этого, в определении причин всего, что он совершает, включая и его общественно опасное поведение. С учетом новых знаний и в совокупности с достижениями двух других направлений антропология в современных условиях вполне способна оказаться в авангарде всей уголовно-правовой политики, заняв при этом центральное место и в уголовно-исполнительной системе, сформировать даже примерное представление о которой в ближайшем будущем, с учетом возможного получения принципиально новых знаний о человеке, сейчас, наверное, не возьмется никто.

Нет сомнений, процесс этот не случаен. Он вполне закономерен, что нашло соответствующее подтверждение в основном в специализированной зарубежной литературе нескольких последних столетий. Процесс этот никогда не останавливался и, более того, на протяжении всего XX века получал требуемую подпитку во многих отраслях знаний, начиная от медицины и заканчивая философией. Системный подход к исследованию данной проблемы в конечном итоге привел к возникновению такого явления, как биополити$\kappa a$, о которой впервые в философии заявил в 1978 г. М. Фукко ${ }^{4}$ (Фукко, 2010). Свой вклад в распознавание выделенного ученым явления внесли П. Рикер, а также экзистенциалисты Х. Арендт, Дж. Агамбен, и даже писатели Э. Лимонов («Дисциплинарный санаторий»), К. Исигуро (в пронзительном романе «Не отпускай меня») и многие другие. Суть биополитики можно свести к совокупности технологий ментального и телесного управления человеком. Ее роль уже не в выяснении причин, она вторична, а в контроле и управлении. М. Фуко подобное подчинение понимал как дисциплину, Агамбен - в крайней точке - как редукцию к «голой жизни» - пределу человеческого в человеке. Подоб- ное управление человеком, в отличие от моральной или правовой регуляции, носит буквальный - телесный, «роботизированный» - характер (Бавсун, М. В., Попов, Д. В., 2018, с. 57). Уголовная биополитика как элемент общей биополитики не может существовать самостоятельно. Наоборот, по своей сути она должна выполнять функцию управления и контроля, причем одну из самых сложных и жестких в силу тех мер, которые существуют в данной правовой сфере. Это если и не максимальный уровень такого воздействия, то, безусловно, близкий к нему. Выше только чрезвычайное законодательство, пределов действия которому, как показывает практика (в том числе связанная с регулированием общественных отношений в условиях пандемии), видимо, не существует.

Имея под собой прочную антропологическую основу в виде серьезных как теоретических, так и в особенности эмпирических исследований, выходящих далеко за пределы собственно криминологии и юриспруденции в целом, биополитика оказалась ее закономерным итогом, сферой приложения (реализации) накопленных знаний как о социологии, так и о физиологии и психологии отдельного человека в частности и общества в целом.

В результате биополитика становится властной формой организации жизни индивида. Биополитика вездесуща, она использует юридические инструменты для регуляции тех общественных отношений, которые возникают между людьми уже в качестве субъектов правоотношений. Юридическая ткань социальной жизни становится проводником биополитических императивов постольку, поскольку качественный сдвиг в жизни населения мыслится как следствие упорядочивания общественных отношений правовыми инструментами. Уголовная политика, известная издревле, становится уголовной биополитикой. Являясь частью биополитики, уголовная биополитика в ее максимально широком понимании стала незаменимым инструментом обеспечения самых сложных (и прежде всего пограничных в отношении дихотомий «жизнь / смерть», «свобода / несвобода») аспектов реализации биополитических стратегий. При этом уголовная политика в контексте (бэкграунде) биополитики - не самоцель, а средство достижения цели. Именно поэтому уголовная политика и выступает «задним двором» (backyard) биополитики. Не выставленная напоказ, скрытая на «заднем дворе» биополитики, уголовная политика предстает системой жестких элементов несущих конструкций биополитического проекта (Бавсун М. В., Попов Д. В., 2019, с. 76)

\footnotetext{
4 Хотя, справедливости ради, надо отметить, что учёным сам термин был позаимствован, но именно им впервые обоснован, а точнее, ему было придано то значение, которое максимально близко для настоящего времени. Между тем первые упоминания термина «биополитика» датируются несколько более ранним периодом. Например, Ганс Рейтер использовал его в речи 1934 года для обозначения биологического обоснования концепции нации и государства и в конечном счете их расовой политики. См.: https://ru.wikipedia.org/wiki/Биополитика. Роберт Э. Каттнер использовал его для описания «научного расизма».
} 
Признавая факт существования биополитики в максимально широком представлении, отрицать ее уголовно-правовую составляющую становится невозможно ${ }^{5}$. Отчасти данная мысль следует из уже упомянутой работы М. Фукко, который, как известно, исходил из того, что биовласть формирует нового «персонажа» - население, отличного как от объекта дисциплины (индивид с его телом), так и от объекта политико-правовых теорий (общество). Во-вторых, биополитика имеет дело с коллективными и серийными феноменами, она рассчитана на массовость, но с учетом индивидуальных особенностей типологии. При этом «...преступность является привилегированным местом для реализации биовласти...» (Nieto, 1999). Преступность выступает в качестве приоритетного направления не просто исследования, а эксперимента, необходимого для экстраполяции его результатов как минимум на другие категории населения, а как максимум - на всех. В-третьих, основная задача биовласти - не изменение отдельных феноменов, а «оптимизация» жизни на глобальном уровне (Кобылин, 2011, с. 118-123). Проблематика субъектности - едва ли не центральная для биополитики, а соответственно, и для уголовной биополитики. Разворот от деяния к личности преступника применительно к последней имеет ключевой харак-

тер, так как это вопрос не только ответственности, но и общей превенции. Между тем и для одного, и для второго совершенно необходимо понимать как биологические особенности человека, так и те возможности (кстати, в том числе и потенциальные), которые есть у государства, необходимые для решения задач в данной части. И здесь знания, накопленные за несколько столетий в рамках развития уголовно-антропологического направления, наряду с современным технологическим прогрессом обеспечивают основу биополитики. Без обеих составляющих о таковой сегодня не было бы и речи, либо она присутствовала бы исключительно в фантастических произведениях, не имеющих научного характера.

Итак, ключевая фигура рассматриваемого явления - человек, который при этом выступает в качестве субъекта преступления, именно он и является объектом воздействия, в том числе и уголовно-правового. И в этом плане, начиная с середины XVIII столетия и заканчивая настоящим временем, безусловно, сделано много, в разы увеличились не только знания о человеке, но и производное от этого представления о том, как на него можно воздействовать. Одно неизбежно влечет другое, это неотъемлемые составляющие одного явления. Столь мощная трансформация накопленных знаний о биологических характеристиках человека, наряду с технологическим прогрессом, который сегодня предоставляет по-настоящему колоссальные возможности по вторжению в сферы его физиологии и психологии, не могут оставить в стороне и содержательную сторону наказания. Его «прогресс» в дальнейшем очевиден, позволяя начинать моделировать и некоторые его направления. Впрочем, именно наказание и выступает в качестве традиционного инструмента биополитики, устанавливая максимальные пределы вторжения в человеческое «я». Пока на уровне обсуждения (но уже сам его факт позволяет осознать границы этих возможных пределов) высказываются следующие идеи: аутсорсинг исполнения наказания (телесериал «Черное зеркало», эпизод White Bear), технологии допроса загрузок сознания, показания которых приравниваются к показаниям физического лица (телесериал «Черное зеркало», эпизод White Christmas), виртуальные пытки (Р. Морган «Видоизмененный углерод»), добровольное установление в головной мозг солдата имплантов, в скрытую часть пакета функций которых входит формирование монструозного образа потенциального противника (телесериал «Черное зеркало», эпизод Men Against Fire), роботы-полицейские, осуществляющие административную деятельность (кинофильм «Элизиум»), «охотники за премиальными», имеющие лицензии на отстрел беглых андроидов (Ф. К. Дик «Мечтают ли андроиды об электроовцах?») (Бавсун, М. В., Попов, Д. В., 2018, с. 69).

Впрочем, есть и вполне реалистичные сценарии использования данных антропологического свойства, знание о которых необходимо для корректиров-

\footnotetext{
5 Так, К. Стенсон при обсуждении новых стратегий контроля над преступностью биополитику рассматривает в качестве одного из средств ее реализации. Он утверждает, что различные инструменты управления - религиозные, этнические, экономические, наряду с биополитическими механизмами контроля, могут оказывать существенное влияние на преступность. (Stenson, K., 2005, pp. 265-287).
} 
ки девиантного поведения. Большой интерес в этом отношении представляет опыт, полученный датскими учеными, которые в целях выявления склонности к антиобщественному поведению на ранней стадии развития личности установили многолетнее наблюдение за 4 тыс. мужчин-добровольцев, среди которых были носители лишних Y- и Х-хромосом. Через двадцать лет был получен результат: 41,7 \% мужчин с лишней Y-хромосомой и $18 \%$ с лишней X-хромосомой попали в поле зрения правоохранительных органов. Среди мужчин с нормальным набором половых хромосом преступников оказалось значительно меньше - 9,3 \%, при этом исследователи пришли к выводу, что они имеют такой же низкий уровень интеллекта, как и обладатели лишних хромосом, что, видимо, и является решающим в совершении преступления. Кроме того, у человека с лишней У-хромосомой есть некоторые психологические особенности, благодаря которым он легче переступает черту закона. Он нередко импульсивен и плохо владеет собой, недооценивает опасность и часто обладает инфантильными представлениями о себе и окружающих. Оказалось, что электроэнцефалограмма мозга у некоторых мужчин с лишней Y-хромосомой также имеет патологии.

В связи с этим зарубежные специалисты разработали специальную программу по выявлению лишних хромосом у новорожденных. Семьи, в которых родились дети с хромосомными аномалиями, были взяты на особый учет. Уже в раннем возрасте поведение таких младенцев отличалось от поведения их сверстников. В первые месяцы они были очень спокойны и спали больше, чем их братья и сестры в том же возрасте. После первого года жизни у исследуемых наблюдались неуклюжесть, плохая координация движений, позднее возникли трудности с обучением. Однако внимательное отношение родителей и помощь специалистов значительно улучшили состояние этих детей и их успехи в школе (Чепыжова, 2009). Таким образом, для предупреждения совершения преступлений были использованы в чистом виде социальные методы, при этом основной акцент был сделан на персональных (личностных) характеристиках возможного преступника. Во многом данный подход должен сохраняться уже после совершения общественно опасного деяния, когда эффективность влияния на виновного может определяться не уровнем карательного воздействия, а использованием принципиально иных способов, не связанных с репрессией лица.

Однако и этот многолетний и, безусловно, крайне важный эксперимент на сегодня уже отчасти устарел, не поспевая за современными технологиями, способными значительно быстрее и в утилитарном порядке сделать значительно больше для такой коррекции. Речь идет о появлении вполне конкретной, а не потенциальной, возможности изменять ДНК, меняя таким образом любые характеристики индивида, включая его склонности к девиантным отклонениям. И это уже реальность, причем реальность, которая была бы невозможна без исследований, длившихся несколько столетий, равно как и сопровождавший их рост технологий, обеспечивающих реализацию антропологического направления в праве. Это та реальность, которой уже не первый год уделяют повышенное внимание, тем самым признавая как сам факт произошедшей в данном направлении революции, так и возможность ее потенциальных угроз ${ }^{6}$.

Антропологи (генетики, биологи, медики и др.) сделали свое дело, технологии его довершили (довершают), превратив в реальность (или в ближайшую возможность таковой) то, о чем еще двадцать лет назад никто не мог даже и подумать. Вполне естественно, что в новых условиях стремительным образом будет меняться и биополитический проект. Новые знания и основанные на них новые возможности будут оказывать соответствующее и, скорее всего, доминирующее влияние на формирование целей и задач. Однако, каковы бы они ни были, как и выбираемые им средства, по своей сути они будут носить жестко утилитарный характер. По-другому и не может быть. Не для того на таком уровне исследовался человек, чтобы в последующем предоставлять ему альтернативу. Вопрос лишь в том, по какому пути пойдет общий биополитичесий проект, а соответственно, и уголовно-политический. По какому пути пойдет общество, через биоанисихию

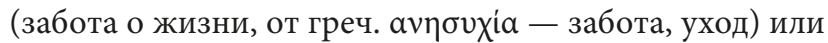
через евгенику в ее крайних проявлениях ${ }^{7}$ ? От этого напрямую будет зависеть и набор тех средств, которыми должно быть наполнено уголовное законодательство.

Надо сказать, что наказание в историческом контексте меняло свою сущность неоднократно. Пережив при этом несколько идейных трансформаций, начиная от мести за совершенное преступление до

\footnotetext{
Cм., например: В Китае на три года осудили генетика за изменение ДНК эмбрионов [Электронный pecypc]. - URL: https://ria. ru/20191230/1563004325.html; Китайский учёный заявил, что впервые в истории изменил ДНК человека [Электронный ресурс]. URL: https://ria.ru/20181126/1533487289.html; Редактирование генома человека преждевременно - ВО3 поддержала позицию России [Электронный ресурc]. - URL: https://news.un.org/ru/story/2019/11/1366751; ВОЗ сформировала экспертный комитет для оценки последствий изменения генов человека [Электронный ресурс]. - URL: https://tass.ru/obschestvo/6119748 и др. (дата обращения: 12.03.2021).

Речь идёт о видении данного направления исключительно через призму биологии и выведения более совершенной «породы» человека. Именно такое представление, например, отстаивал Л. Стоддард (Стоддард, 2016). Следствием подобных увлечений стала радикализация биополитики, в рамках которой стали изобретаться практические инструменты целенаправленного воздействия на население, в том числе и средствами так называемой отрицательной евгеники (Попов, 2020, с. 72).
} 
исправления виновного лица, транзитом через начало устрашения, оно неизменно выполняло карательную функцию. Кара и возмездие всегда выступали в качестве традиционных спутников наказания, со временем лишь меняясь по своей форме выражения и видам сообразно развитию общественных отношений, в которых оно существовало и применялось. Однако по мере усложнения биополитического проекта усложняется и уголовная политика, и не в последнюю очередь в части формирования объема уголовной репрессии. Развитые социальные отношения, развитая экономика, инклюзивные политические институты масштабируют биополитические задачи и существенно усложняют задачи репрессивного аппарата. Они вновь становятся другими, постепенно заменяя кажущуюся вечной идею исправления виновного и предупреждения совершения им нового преступления (исправление-предупреждение). Вторжение в сферу личного стало настолько явным, а чем дальше, тем и более управляемым с позиции знаний и технологий, что все чаще начинает озвучиваться идея постчеловека, реализация которой уже не позволяет опираться на прежние формы и методы воздействия. Антропологические предпосылки современной биополитики сегодня позволяют подминать саму идею человека. Появляющиеся возможности по управлению его сознанием говорить о человеке как таковом уже не позволяют. Отсюда и появление нового направления как в науке, так и в литературе - идея постчеловека, абсурдность которой еще два десятилетия назад не обсуждалась. Но, допуская идею постчеловека, впору задуматься об иных идеях в праве, так как прежние оказываются совершенно непригодными в условиях предложенного сценария.

Первые шаги антропологического характера, несмотря на давность своего происхождения, в конечном итоге оказались в роли ключевой предпосылки для трансформации идеи возможного влияния (в том числе и средствами уголовно-правового характера) на человека. Применительно к уголовно-правовому воздействию речь в дальнейшем может идти о потенциальной способности привести человечество к индивидуальной норме и индивидуальному правосудию, на весах которого с абсолютной точностью определяется мера ответственности, а также должная мера и характер наказания уникальной личности, совершившей деяние. Безусловно, подобное возможно лишь в идеале, и опять же в зависимости от поставленных целей и задач биополитического проекта. Важным в данном случае видится потенциальный переход в наказании от идеи исправления (исправления-предупреждения), прочно укоренившейся в мировой практике, к функции контроля (контроля-исправления). Доминирование контроля в уголовном праве в случае дальнейшей реализации биополитического проекта представляется неизбежным. Более того, все чаще начинают звучать тезисы, обосновывающие тот факт, что рациональность предупреждения преступности в своей основе сводится к почти тоталитарной биополитической стратегии, поскольку она фокусируется практически на всех аспектах жизни человека от здоровья до контроля его поведения в отдельных жизненных ситуациях (Borch, 2005). Открытым пока остается лишь вопрос относительно конкретных форм такого контроля, его пределов и направленности в зависимости от целей, а от этого - и ожидаемых результатов. Ключевым является тот факт, что реализация функции контроля в уголовном праве может быть обеспечена только за счет биополитического инструментария ${ }^{8}$. Именно биополитика как апофеоз антропологического направления предоставляет максимальные возможности в этом направлении.

\footnotetext{
${ }^{8}$ Хотя следует отметить, что в современной литературе высказывается позиция, согласно которой биополитика оценивается как мощное, но не самое перспективное средство контроля над поведением человека. Так, П.С. Лалонд, описывая формы контроля социального поведения, приходит к выводу, согласно которому биополитические инструменты контроля начинают все больше уступать кибернетическим средствам. Иллюстрируя их применение, Патрик Лалонд показывает новую, пост-паноптикумную концепцию охраны правопорядка. Следуя ей, население не нуждается в постоянном надзоре со стороны государства. Существующие интернет-технологии выполняют эту задачу, фиксируя и сохраняя цифровые следы решений и поступков индивидов. Их обработка и анализ позволяют оценивать склонность к криминальному поведению, а также ограничивать возможность доступа индивидов к различным ресурсам. См. об этом более подробно (Lalonde, P., 2017, pp. 1361-1380)
} 


\section{Список митературы}

Borch, C. (2005). Crime Prevention as Totalitarian Biopolitics. Journal of Scandinavian Studies in Criminology and Crime Prevention (6), 91-105.

Lalonde, P. C. (2017). Cyborg Work: Borders as Simulation. The British Journal of Criminology, 58 (6), 1361-1380. doi:10.1093/bjc/azx070.

Nieto, D. (1999). Neoliberalismo, biopolítica yobernanza del crimen transnaciona// URL:http://. Получено 01.04 .2021 г., из www.scielo: $w$ ww.scielo.org.co/scielo.php?script=sci_arttext\&pid=S0121-56122012000200006

Stenson, K. (2005). Sovereignty, biopolitics and the local government of crime in Britain. Theoretical Criminology, 9 (3), 265-287. doi:10.1177/1362480605054811.

Ашаффенбург, Г. (2010). Преступление и борьба с ним. Уголовная психология для врачей, юристов и соииологов. Москва: ИНФРА-М.

Бабаев, М. М., Пудовочкин, Ю. Е. (2021). Очерки криминальной рискологии. Москва: Юрлитинформ.

Бавсун, М. В., Попов, Д. В. (2018). Метамодерн в праве: осцилляция в точке Канетти. Статья І. Пролиферация норм и разум. Научный вестник Омской академии МВД России (4), 62-70.

Бавсун, М. В., Попов, Д. В. (2019). Биополитический «бэкграунд» уголовной политики. Философия права (4), $75-84$.

Баршев, С. (1840). О мере наказания. Санкт-Петербург.

Гернет, М. (1974). Избранные произведения. Москва: Юрид. лит.

Гогель, С. (1910). Курс уголовной политики в связи с уголовной соииологией. Санкт-Петербург: Юрид. кн. скл. «Право».

Горегляд, О. (1815). Опыт начертания российского уголовного права. О преступлениях и наказаниях вообще. Санкт-Петербург.

Гуляев, П. (1826). Российское уголовное право, составленное из российских государственных узаконений. Москва.

Дриль, Д. (1904). Наука уголовной антропологии, ее предмет и задачи. Вестник психологии, криминальной антропологии и гипнотизма (1), 12-20.

Кобылин, И. (2011). Возвышенный объект биополитики (Дж. Агамбен о проблеме свидетельства). Вестник Нижегородского университета им. Н.И. Лобачевского. Серия Социальные науки (3), 118-123.

Лист, Ф. ф. (1900). Преступление как социально-патологическое явление. Санкт-Петербург: тип. А.В. Орлова.

Ной, И. (1975). Методологические проблемы советской криминологии. Саратов: Изд-во Сарат. ун-та.

Овчинский, В. (2005). Криминология и биотехнологии. Москва: Норма.

Познышев, С. (2007). Криминальная психология. Преступные типы. О психологическом исследовании тичности как субъекта поведения вообще и об изучении личности преступника в частности. Москва: ИНФРА-М.

Попов, Д. (2020). От конструирования к апгрейду жизни: расцвет или кризис биополитики? Человек, 31 (6), 68-86.

Прозументов, Л. (2016). О происхождении антропологического направления в уголовном праве и криминологии. Криминологический журнал Байкальского государственного университета экономики и права, 10 (1), 20-27.

Прозументов, Л. М., Шеслер, А. В. (2014). Отечественные научные концепции причин преступности. Криминологический журнал Байкальского государственного университета экономики и права (1), 49-58.

Солнцев, Г. (1820). Российское уголовное право. Казань.

Соловьев, В. (2014). Проповедник в пустыне: проповеди о праве (избранные труды). Москва: Статут.

Сорокин, П. (2006). Преступление и кара. Подвиг и награда. Москва: Астрель.

Стоддард, Л. (2016). Бунт против цивилизации. (В. Авдеева, Ред., \& Д. Ткаченко, Перев.) Москва: Белые альвы.

Таганцев, Н. (1903). Курсуголовного права. Русское уголовное право (Т. 1). Санкт-Петербург: тип. М. Стасюлевича. 
Тард, Г. д. (2009). Преступник и преступление. Сравнительная преступность. Преступления толпь. Москва: Инфра-М.

Тарновская, П. (1891). Воровки. Антропологическое исследование. Журнал русского общества охранения народного здравия, (5), 63-64.

Тарновская, П. (1902). Женщины-убийцы. Антропологическое исследование. Санкт-Петербург: Т-во худож. печати.

Торвальд, Ю. (1990). Век криминалистики. (Ф. Решетников, Ред.). Москва: Прогресс.

Фельдштейн, Г. С. (2003). Главные течения в истории науки уголовного права в России. Москва: Зерцало.

Фукко, М. (2010). Рождение биополитики. Курс лекиий, прочитанный в Коллеж де Франс в 1978-1979 учебном году. Санкт-Петербург: Наука.

Чепыжова, Е. (2009). Генетический пасьянс: хромосома преступника. Получено 30.03 .2021 г., из abc-gid.ru: www. abc-gid.ru/articles/show/147/.

Чиж, В. (1895). Криминальная антропология. Одесса: Г. Бейленсон и И. Юровский.

Чубинский, М. (1905). Очерки уголовной политики. Харьков: типография «Печатное Дело».

\section{References}

Borch, C. (2005). Crime Prevention as Totalitarian Biopolitics. Journal of Scandinavian Studies in Criminology and Crime Prevention (6), 91-105.

Lalonde, P. C. (2017). Cyborg Work: Borders as Simulation. The British Journal of Criminology, 58 (6), $1361-1380$. doi:10.1093/bjc/azx070.

Nieto, D. (1999). Neoliberalismo, biopolítica y gobernanza del crimen transnaciona//URL: http://. Polucheno 01.04.2021 g., iz www.scielo: www.scielo.org.co/scielo.php?script=sci_arttext\&pid=S0121-56122012000200006.

Stenson, K. (2005). Sovereignty, biopolitics and the local government of crime in Britain. Theoretical Criminology, 9 (3), 265-287. doi:10.1177/1362480605054811.

Aschaffenburg, G. (2010). Crime and the fight against it. Criminal psychology for doctors, lawyers and sociologists. Moscow: INFRA-M.

Babaev, M. M., Pudovochkin, Yu. E. (2021). Essays on Criminal Riskology. Moscow: Yurlitinform.

Bavsun, M. V., Popov, D. V. (2018). Metamodern v prave: ostsillyatsiya v tochke Kanetti. Stat'ya I.Proliferatsiya norm i razum. Nauchnyy vestnik Omskoy akademii MVD Rossii (4), 62-70.

Bavsun, M. V., Popov, D. V. (2019). Biopoliticheskiy «bekgraund» ugolovnoy politiki. Filosofiya prava (4), 75-84.

Barshev, S. (1840). O mere nakazaniya. Saint Petersburg.

Gernet, M. (1974). Izbrannyye proizvedeniya. Moskow: Yurid. lit.

Gogel', S. (1910). Kurs ugolovnoy politiki v svyazi s ugolovnoy sotsiologiyey. Saint Petersburg: Yurid. kn. skl. «Pravo».

Goreglyad, O. (1815). Opyt nachertaniya rossiyskogo ugolovnogo prava. O prestupleniyakh i nakazaniyakh voobshche. Saint Petersburg.

Gulyayev, P. (1826). Rossiyskoye ugolovnoye pravo, sostavlennoye iz rossiyskikh gosudarstvennykh uzakoneniy. Moskow.

Dril', D. (1904). Nauka ugolovnoĭ antropologii, yeye predmet i zadachi. Vestnik psikhologii, kriminal'nŏ antropologii i gipnotizma (1), 12-20.

Kobylin, I. (2011). Vozvyshennyy ob”yekt biopolitiki (Dzh. Agamben o probleme svidetel'stva). Vestnik Nizhegorodskogo universiteta im. N.I. Lobachevskogo. Seriya Sotsial'nyye nauki (3), 118-123.

List, F. f. (1900). Prestupleniye kak sotsial'no-patologicheskoye yavleniye. Saint Petersburg: tip. A.V. Orlova.

Noy, I. (1975). Metodologicheskiye problemy sovetskoy kriminologii. Saratov: Izd-vo Sarat. un-ta.

Ovchinskiy, V. (2005). Kriminologiya i biotekhnologii. Moskow: Norma, 28.

Poznyshev, S. (2007). Kriminal'naya psikhologiya. Prestupnyye tipy. O psikhologicheskom issledovanii lichnosti kak sub»yekta povedeniya voobshche i ob izuchenii lichnosti prestupnika v chastnosti. Moskow: INFRA-M.

Popov, D. (2020). Ot konstruirovaniya k apgreydu zhizni: rastsvet ili krizis biopolitiki? Chelovek, 31 (6), 72. 
Prozumentov, L. (2016). O proiskhozhdenii antropologicheskogo napravleniya v ugolovnom prave i kriminologii. Kriminologicheskiy zhurnal Baykal'skogo gosudarstvennogo universiteta ekonomiki i prava, 10(1), 20-27.

Prozumentov, L. M., Shesler, A. V. (2014). Otechestvennyye nauchnyye kontseptsii prichin prestupnosti. Kriminologicheskiy zhurnal Baykal'skogo gosudarstvennogo universiteta ekonomiki i prava (1), 49-58.

Solntsev, G. (1820). Rossiyskoye ugolovnoye pravo. Kazan'.

Solov'yev, V. (2014). Propovednik v pustyne: propovedi o prave (izbrannyye trudy). Moskow: Statut.

Sorokin, P. (2006). Prestupleniye i kara. Podvig i nagrada. Moskow: Astrel'.

Stoddard, L. (2016). Bunt protiv tsivilizatsii. (V. Avdeyeva, Red., \& D. Tkachenko, Perev.) Moskow: Belyye al'vy.

Tagantsev, N. (1903). Kurs ugolovnogo prava. Russkoye ugolovnoye pravo (T. 1). Saint Petersburg: tip. M. Stasyulevicha. Tard, G. d. (2009). Prestupnik i prestupleniye. Sravnitel'naya prestupnost'. Prestupleniya tolpy. Moskow: Infra-M.

Tarnovskaya, P. (1891). Vorovki. Antropologicheskoye issledovaniye. Zhurnal russkogo obshchestva okhraneniya narodnogo zdraviya (5), 63-64.

Tarnovskaya, P. (1902). Zhenshchiny-ubiytsy. Antropologicheskoye issledovaniye. Saint Petersburg: T-vo khudozh. pechati.

Torval'd, Yu. (1990). Vek kriminalistiki. (F. Reshetnikov, Red.). Moskow: Progress.

Fel'dshteyn, G. S. (2003). Glavnyye techeniya v istorii nauki ugolovnogo prava v Rossii. Moskow: Zertsalo.

Fukko, M. (2010). Rozhdeniye biopolitiki. Kurs lektsiy, prochitannyy v Kollezh de Frans v 1978-1979 uchebnom godu. Saint Petersburg: Nauka.

Chepyzhova, Ye. (2009). Geneticheskiy pas'yans: khromosoma prestupnika. Polucheno 30.03 .2021 g., iz abc-gid.ru: www.abc-gid.ru/articles/show/147/.

Chizh, V. (1895). Kriminal'naya antropologiya. Odessa: G. Beylenson i I. Yurovskiy.

Chubinskiy, M. (1905). Ocherki ugolovnoı̆ politiki. Kharkov: printing house «Printing Business».

\section{Информация об авторе:}

Бавсун Максим Викторович - заместитель начальника Санкт-Петербургского университета МВД России (по научной работе), доктор юридических наук, профессор, Санкт-Петербург, Россия.

\section{About the author:}

Bavsun Maksim Viktorovich - Deputy Head of the St. Petersburg University of the MIA of Russia (for scientific work), Doctor Sci. (Jurid.), Professor, Saint Petersburg, Russia.

Статья поступима в редакцию 01.03.2021; одобрена после рецензирования 15.04.2021; принята к публикации 30.04.2021.

The article was submitted March 3, 2021; approved after reviewing April 15, 2021; accepted for publication April 30, 2021.

Автор заявляет об отсутствии конфликта интересов.

The author declare no conflicts of interests. 